\title{
FREE AMINO ACIDS IN THE SHRIMP CRANGON GRANGON AND THEIR OSMOREGULATORY SIGNIFICANCE
}

\author{
by \\ R. E. WEBER \\ (Netherlands Institute for Sea Research, Texel, The Netherlands) \\ and \\ W. J. A. VAN MARREWIJK \\ (Laboratory for Chemical Animal Physiology, University of Utrecht, The Netherlands)
}

\section{CONTENTS}

I. Introduction. . . . . . . . . . . . . . . . . . . . . . . . . . 391

1. The cellular regulation and mechanisms involved. . . . . . . . . 392

2. Application to Crangon . . . . . . . . . . . . . . . . . . . . 393

II. Material and Methods . . . . . . . . . . . . . . . . . . . . . 395

1. Animals and acclimations . . . . . . . . . . . . . . . 395

2. Concentrational determinations . . . . . . . . . . . . . . . . 395

III. Results and Interpretation. . . . . . . . . . . . . . . . . . . . 397

1. Muscle tissue concentrations. . . . . . . . . . . . . . . . . . 397

Water content. . . . . . . . . . . . . . . . 397

Ninhydrin-positive substance . . . . . . . . . . . . . 398

Free amino acids . . . . . . . . . . . . . . . . . . . . . . 400

2. Haemolymph concentrations . . . . . . . . . . . . . 403

Ninhydrin-positive substance . . . . . . . . . . . . . . 403

Free amino acids . . . . . . . . . . . . . . . . . . . . . . 404

3. Accommodation rate. . . . . . . . . . . . . . . . . 407

Muscle tissue . . . . . . . . . . . . . . . . . . 407

Haemolymph . . . . . . . . . . . . . . . . 407

IV. General Discussion . . . . . . . . . . . . . . . . . . . . 409

V. Summary . . . . . . . . . . . . . . . . . . . . . . . . . . 412

VI. References . . . . . . . . . . . . . . . . . . 413

\section{INTRODUCTION}

In 1901 already Frederice postulated on the basis of taste, ash contents and freezing point observations, that small organic molecules constitute significant osmotic effectors in the tissue cells of marine invertebrates. Yet the regulation processes involved in maintaining the cell contents isosmotic to the haemolymph i.e. the "isosmotic intracellular regulation" ( $c f$. FLORKIN \& SchOFfENIELS, 1969) has in contrast to the "anisosmotic extracellular regulation" of haemolymph concentrations, only become subject to more intensive study in the 
last two decades, despite the indicated presence of the former process in all euryhaline invertebrates investigated. This paper reports the role of amino acids and other small nitrogenous molecules in the regulation of osmotic concentrations in the euryhaline shrimp Crangon crangon.

\section{THE GELLULAR REgULATION AND MEGHANISMS INVOLVED}

The isosmotic intracellular regulation continually adjusts the cellular osmotic concentrations to environmentally induced variations in haemolymph osmolarity. The role played by free amino acids in the osmoregulation of crustacean cells has been illustrated in several investigations (c.f. SHAw, 1958; FLoRkin and co-workers: CAMIEN et al., 1951; Florkin et al., 1964; Florkin \& Schoffeniels, 1969). Although these studies were generally limited to two salinities, they indicate that while the cellular inorganic component remains relatively constant, the organic component tends to vary in parallel with environmental salinity. These concentration changes exceed those due to concomitant salinity-induced tissue hydration.

Studying the processes of osmotic adaptation of the cells necessarily implicates the regulation of cell volume and water content ( $c f$. SHAw, 1958). In fact the capability to volume regulate is a measure of the completeness of the overall isosmotic intracellular regulation of the animal concerned (LANGE, 1970), since changes in the volume of the cells always seem involved (Prosser, 1965). Florkin \& SchofFENIELS (1969) further consider that the highly-organized cell interior resembling the physico-chemical state of a gel rather than a true solution, together with the indicated absence of Gibbs-Donnan equilibrium, argues for the presence of mechanisms which avoid bursting of the cells, and suggest that the amino acids contained affect a reduction of intracellular water activity.

With regard to the mechanisms regulating the intracellular free amino acids (FAA), SchoffenIels (1960) put forward the hypothesis that the activities of enzyme systems directly involved in amino acid metabolism are differentially affected by salinity-induced changes in haemolymph cation concentrations. Observations on several enzyme systems involved, have amply illustrated this effect in vitro (Chaplin, Huggins \& Munday, 1965; Florkin \& Schoffeniels, 1969; Schoffeniels, $1965,1968)$. Moreover, the quantitative and qualitative characteristics of the amino acid pools in the nervous system of arthropods are correlable with differences in activities of enzymes controlling amino acid metabolism (Pasantes et al., 1965). Again an ecological correlation 
is provided by GrLLes (1967) who found different salt interactions of malate and serine hydrolases, depending on whether these were isolated from muscles of euryhaline crustaceans (Carcinus maenas, Eriocheir sinensis, Astacus fuviatilis (=A. astacus)) or stenohaline ones (Homarus vulgaris, Maia squinado). That the regulatory mechanism may not solely involve specific ionic interactions with synthesizing and catabolizing enzyme systems is, however, evident from the observations of Kaneshiro, Holz \& Dunham (1969) that in the ciliate Miamensis avidus the intracellular FAA changes in response to external osmotic pressure rather than in response to altered ionic concentrations.

The presence of FAA regulation in isolated lobster nerves argues against an endocrinal involvement (Schofreniels, 1960). Again the constancy of the protein component of isolated nerves of the crab Eriocheir sinensis adapted to fresh and to sea water makes it improbable that amino acids are regulated by modification of the steady state between cell proteins and faA (Gilles \& Sahoffeniels, 1969). Moreover, a comparison of proline and alanine concentrations before and after protein hydrolysis, in muscle tissues of Eriocheir adapted to fresh water and to sea water indicates a net synthesis of both amino acids in the sea water (FLORkIN et al., 1964). The concomitance of increased ammonia excretion with lowered amino acid levels, in various marine echinoderm, annelid, crustacean and molluscan representatives (FLoRKin et al., 1964; Emerson, 1969; Needham, 1957; Florkin \& SchoffeNIELs, 1965) tallies with the synthesis-degradation theory. Gilles \& Schoffeniels (1969) experiments with isolated Eriocheir nerves, however, suggest that whereas the synthesis-degradation hypothesis applies to the non-essential amino acids, tyrosine, phenylalanine, valine, leucine and iso-leucine appear to be regulated by modification of the permeability of the cell membrane. With the exception of tyrosine, all these amino acids have been shown essential to the crayfish Astacus astacus (ZANDEE, 1966). For the non-essential proline, however, Vincent-MariQue \& Gilles (1970a, 1970b) record similar extrusion from the cells of Eriocheir during acclimation to lower salinity, whereby haemolymph values may show a temporary six-fold increase.

\section{APPLIGATION TO GRANGON}

The free amino acid pool of invertebrates is more concentrated than in vertebrates: among the former it is more concentrated in marine than in fresh water forms (Cowey, 1961; Emerson, 1966; Simpson et al., 1959). This indicates that marine crustaceans dispose over a large potential of cellular osmotic adjustment.

Crangon crangon is euryhaline and shows a seasonal migration to the 
fresher coastal and Wadden Sea waters in summer and to more saline offshore waters in winter (BRoEkema, 1941; Verwey, 1957). No measurements of the salinity-induced variation in free amino acids (FAA) or other ninhydrin-positive substance (NPS) in haemolymph or tissue cells appear to have been carried out. FyHN (1966), however, records that the cellular NPS varies in parallel with blood osmolarity during the moult cycle, indicating the active participation of the intracellular isosmotic regulation in ecdysis.

The haemolymph similarly shows evidence for osmotically significant amounts of non-electrolytes, as may be deduced from a comparison of conductivity and cryoscopic measurements (respectively: BROEKEMA, 1941; Weber \& SpaArgaren, 1970). This similarly applies to Baltic specimens (FLÜGEL, 1963) despite of a significantly different pattern of extracellular anisosmotic regulation (WEBER \& SPAARGAREN, 1970). Comparing the thus indicated non-electrolyte concentrations of haemolymph with those of whole-animal homogenates, SpaArgaren (1971) indicates that while the organic component of the homogenates shows overall direct variation with salinity, it appears to be inversely related to non-electrolyte in the haemolymph. The non-electrolyte in haemolymph could attain freezing-point depression values $(\Delta)$ of $0.2^{\circ} \mathrm{C}$; for the homogenates the corresponding value is approximately $0.6^{\circ} \mathrm{C}$ at $30 \% \mathrm{~S}$.

Although a parallel study of the concentrations in both muscle tissue and haemolymph appears of direct relevance to the evaluation of a possible coupling between the regulation of nitrogenous material in these two tissues ( $c f$. HARRIs, 1969) it has thusfar only been carried out in isolated species-cf. Eriocheir sinensis (VINCENT-MARIQUE \& Gilles, 1970) - and generally limited to two salinities. This paper describes direct measurements of the contribution of ninhydrin-positive substance and free amino acids to the above indicated organic component in tissue and haemolymph of Crangon. These experiments, designed to gain insight into the component processes responsible for the regulation of internal osmotic pressures, were carried out after adaptation to a range of environmental conditions, and during the course of salinity acclimation. The results are interpreted comparatively and in terms of the above-outlined possible regulatory mechanisms involved.

In this paper the terms "regulation" will imply the independency of internal concentrations from ambient salinity, and "conformity" a parallel variation of internal and external concentrations. When an increase in salinity or temperature is associated with a decrease in internal concentrations, its effect will be termed "inverse"; when on the other hand the internal concentration responds with a parallel variation it will be termed "direct". 
Acknowledgments.-We are indebted to Mr. G. W. Kraay (Texel) and Mr. H. J. L. Ravestein (Utrecht) for valuable technical assistance. Additional technical help from Mr. E. Pauptit and Mrs. A. PorsiusBleeker (Texel) during the course of the experimental work is gratefully acknowledged. Thanks are further due to Dr. D. H. Spaargaren for critical reading of the manuscript and to Dr. J. Verwey for stimulating interest and discussions.

\section{MATERIALS AND METHODS \\ 1. ANIMALS AND ACGLIMATIONS}

Specimens of Crangon crangon L. were trawled with the Institute's research vessel "Ephyra" from the Marsdiep-Texelstroom in the Wadden Sea, mainly between Den Helder (North Holland) and Oudeschild (Texel island), in waters with salinities of about 26 to $33 \% \mathrm{~S}$ and stored until the beginning of the experiments in fishwells submerged in the harbour of the Netherlands Institute for Sea Research, on Texel. Males as well as non-gravid females of 4 to $6 \mathrm{~cm}$ in length were used. The animals were acclimated to different salinities and temperatures in glass aquaria provided with a bottom filter of shell grit covered with sand. An inverted glass funnel partially embedded in the sand and covering a diffuser block (air supply) provided circulation by air-lift. Per aquarium with bottom area of about $700 \mathrm{~cm}^{2} 10$ to 15 animals were introduced. Acclimation salinities were obtained by addition of commercially available sea salts or of distilled water to sea water from the supply of the institute. Shrimps acclimated to $5 \% \mathrm{~S}$ were preadapted at $10 \% \mathrm{~S}$ for 3 days. When in good condition the animals burrowed in the sand, and the mortality was extremely low during the minimal acclimation period of 8 days.

In view of the indicated decrease in the FAA content of Carcinus maenas during post-exuvial stages (Duchâteau, Florkin \& Jeuniaux, 1959), animals with soft exoskeletons were not used in the experiments. For the assay of the concentrations of tissue FAA, only animals were used, which at the end of the acclimation, were in the intermoult phases $\mathrm{C}_{\beta}, \mathrm{D}_{1}{ }^{\prime}$ and $\mathrm{D}_{1}{ }^{\prime \prime}$ of Drach's (1944) classification for Natantia.

\section{CONGENTRATIONAL DETERMINATIONS}

Haemolymph was drawn by piercing the pericardial cavity with finely drawn-out, calibrated glass capillaries. To measure the concentrations in muscles, the abdominal flexors and extensors were removed, carefully 
blotted with tissue paper and weighed directly. The water contents of the muscles were gravimetrically determined after oven-drying at $80^{\circ} \mathrm{C}$ for 3 days.

\section{Ninhydrin-positive substance (NPS)}

The abdominal musculature of individual shrimps were thoroughly homogenized in a Potter tube with $5 \mathrm{ml}$ distilled water immediately after removal from the animals. After centrifugation $(10 \mathrm{~min}$ at 3000 $\mathrm{rev} / \mathrm{min}) 10 \mu 1 \mathrm{samples}$ of the supernatant, or $20 \mu 1$ samples of haemolymph were then diluted to $0.1 \mathrm{ml}$ with distilled water, and deproteinized by the addition of $0.3 \mathrm{ml}$ methanol-acetone vol./vol. $=3 / 1$ (Clotten \& Clotten, 1962). The solution was subsequently stood in the cold for 1 hour, the precipitate centrifuged off, and the concentration of NPS was determined on $0.2 \mathrm{ml}$ aliquots of the supernatant, according to the method of Moore \& STEIN (1948). The colour reaction was measured at $570 \mathrm{~nm}$ with solutions of DL-leucine as standard.

\section{Free amino acids (FAA)}

Measurement of the FAA in muscle homogenates and haemolymph was preceded by the following extraction procedure. Samples of the fluid of $0.5 \mathrm{ml}$ were freeze-dried in screw-top polypropylene tubes. To this $10 \mathrm{ml} 70 \%$ ethanol was added and the closed tubes were left overnight in the cold. The samples were then centrifuged at $7700 \times g$ and $4^{\circ} \mathrm{C}$ for one hour and the supernatants collected. To this was added the supernatants of 2 further ethanol washings with $5 \mathrm{ml}$ and $2 \mathrm{ml}$ alcohol, respectively. The lipids were subsequently removed from the combined supernatants by the addition of 6 times its volume of chloroform. The mixture was shaken and stood overnight at $4^{\circ} \mathrm{C}$. The water phase was removed and the chloroform washed successively with $5 \mathrm{ml}$ and $2 \mathrm{ml}$ $0.01 \mathrm{~N} \mathrm{HCl}$. The water fractions were pooled and freeze-dried. The residues were then dissolved in $2.0 \mathrm{ml} \mathrm{Li}$-citrate buffer $(\mathrm{pH} \mathrm{2.2)}$ and filtered through glass filter.

Amino acid analyses were carried out with a Biocal BC-200 Automatic Amino Acid Analyser using a two-column system (Spackman, STEIN \& Moore, 1958). The acidic and neutral amino acids were resolved in a $60 \times 0.9 \mathrm{~cm}$ column filled to a height of $54 \mathrm{~cm}$ with Bio-Rad Aminex A6 ion-exchange resin, and eluted with $0.3 \mathrm{~N} \mathrm{Li}$ citrate buffer, $\mathrm{pH} 2.92$ and $37.0^{\circ} \mathrm{C}(0-185 \mathrm{~min})$ and $\mathrm{pH} 4.10$ and $53.5^{\circ} \mathrm{C}(185-310 \mathrm{~min})$. The basics were analysed using a column filled to $24 \mathrm{~cm}$ with Aminex A5 resin, and eluted successively with $0.38 \mathrm{~N} \mathrm{Na}$-citrate buffer $\mathrm{pH} 4.26$ and $30^{\circ} \mathrm{C}(0-145 \mathrm{~min})$ and $0.35 \mathrm{~N}$ 
buffer, $\mathrm{pH} 5.28$ and $50^{\circ} \mathrm{C}(145-330 \mathrm{~min})$. The amino acids were eluted at $60 \mathrm{ml}$. hr ${ }^{-1}$. The ninhydrin reaction was measured in continuous flow cuvettes at $440 \mathrm{~nm}$ and at $570 \mathrm{~nm}$.

\section{RESULTS AND INTERPRETATION \\ 1. MUSGLE TISSUE GONGENTRATIONS \\ Water content}

The water content of muscles from animals adapted to different salinities at $5^{\circ} \mathrm{C}$ were determined (Fig. 1) in order to estimate the influence of salinity-dependent tissue hydration on the measured concentrations and to estimate molal concentrations of measured solutes. On the basis of these data, the linear regression (Fig. 1) relating the percentage water content $(W)$ and salinity in \% $(S)$, may be characterized by the equation:

$$
\begin{gathered}
W=-0.108 S+80.04 \\
\text { (correlation coefficient }=0.81, \mathcal{N}=24) .
\end{gathered}
$$

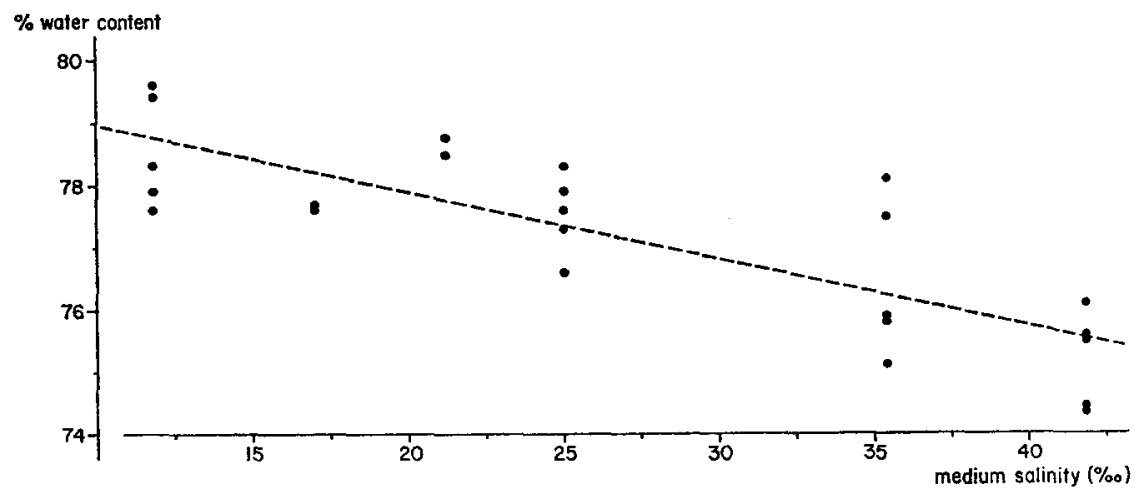

Fig.1. Water content of the abdominal muscles of $C$. crangon as a function of medium salinity at $5^{\circ} \mathrm{C}$.

The low negative linear regression coefficient between salinity and water content indicates an efficient volume - and thus intracellular isosmoticregulation; it is in fact lower than that which may be calculated (-0.18) from Shaw's (1958) data for muscle fibres of the well known euryhaline representative Carcinus maenas. 
TABLE I

Levels of significance of the temperature induced variation in muscle NPs (student's t-test) from data represented in Fig. 2 are as follows. The figures in brackets show the degrees of freedom $\left(n_{1}+n_{2}=2\right) ; n s=$ not significant.

\begin{tabular}{ccccc}
\hline Approximate salinity & \multicolumn{4}{c}{ Temperatures compared $\left({ }^{\circ} \mathrm{C}\right):$} \\
\cline { 2 - 3 }$\%$ & 5 and 15 & 5 and 21 & 15 and 21 \\
\hline 26 & $\mathrm{p}<0.05(13)$ & $\mathrm{p}<0.01(16)$ & $\mathrm{ns}$ & $(14)$ \\
35 & $\mathrm{p}<0.005(14)$ & $\mathrm{p} \pm 0.01(16)$ & $\mathrm{ns}$ & $(16)$ \\
40 & $\mathrm{p}<0.005(14)$ & $\mathrm{p} \pm 0.05(14)$ & $\mathrm{p}<0.005(14)$ \\
\hline
\end{tabular}

Ninhydrin positive substance (NPS)

The NPS values determined as a function of salinity at three acclimation temperatures (Fig. 2, Table I) show clear direct variation with ambient salinity. These changes are markedly in excess of those attributable to hydration effects. Thus, for the $5^{\circ} \mathrm{C}$ data, it will be evident that for a salinity decrease from 35 to $10 \% \mathrm{~S}$ the NPS decreased by about $47 \%$. Assuming the solute content to be invariant with salinity, a comparison of the amount of water associated with unit dry weight at different salinities reveal that the increased hydration associated with a transfer from 35 to $10 \% \mathrm{~S}$ could account at most for a $14 \%$ reduction in solute concentration.

In order to estimate the osmoregulatory significance of these values, the NPS concentrations per $\mathrm{kg}$ fresh weight should be expressed per $\mathrm{kg}$ solvent, by multiplying by the factor $1000 W^{-1}$ (where $W$ is water content in grams per $\mathrm{kg}$ fresh tissue at the salinity in question, $c f$. Fig. 1). In the absence of knowledge of the weighted mean of osmotic coefficients and assuming the presence of one ninhydrin-positive nitrogen atom per molecule of NPS, the approximate freezing-point depressions $(\Delta)$ of NPS in whole muscle may be calculated from the molal freezing point depression of water $\left(1.858^{\circ} \mathrm{C}\right) . \Delta$-values thus obtained for the $5^{\circ} \mathrm{C}$ NPS data amount to $0.52^{\circ} \mathrm{C}$ and $1.24{ }^{\circ} \mathrm{C}$ at $10 \% \mathrm{~S}$ and $35 \% \mathrm{~S}$, respectively. Comparing these values with the $\Delta$-values of haemolymph under corresponding conditions, respectively about $0.9^{\circ} \mathrm{C}$ and $1.70^{\circ} \mathrm{C}$ (Weber \& SpaArgaren, 1970), suggests that in Crangon, NPS is the main factor responsible for adapting intracellular osmotic pressures to those of the haemolymph. Since the intracellular fluid may be considered isosmotic to haemolymph (FLORKIN \& SaHoffeniels, 1965; RoBertson, 1965) the more or less constant differences between the $\Delta$-values in haemolymph and that due to muscle NPS at these salinities, confirms a relative constancy in the cellular electrolyte 
component. Similar interpretations are illustrated by the salinityinduced NPS variation obtained at the other experimental temperatures $\left(15\right.$ and $\left.22^{\circ} \mathrm{C}\right)$.

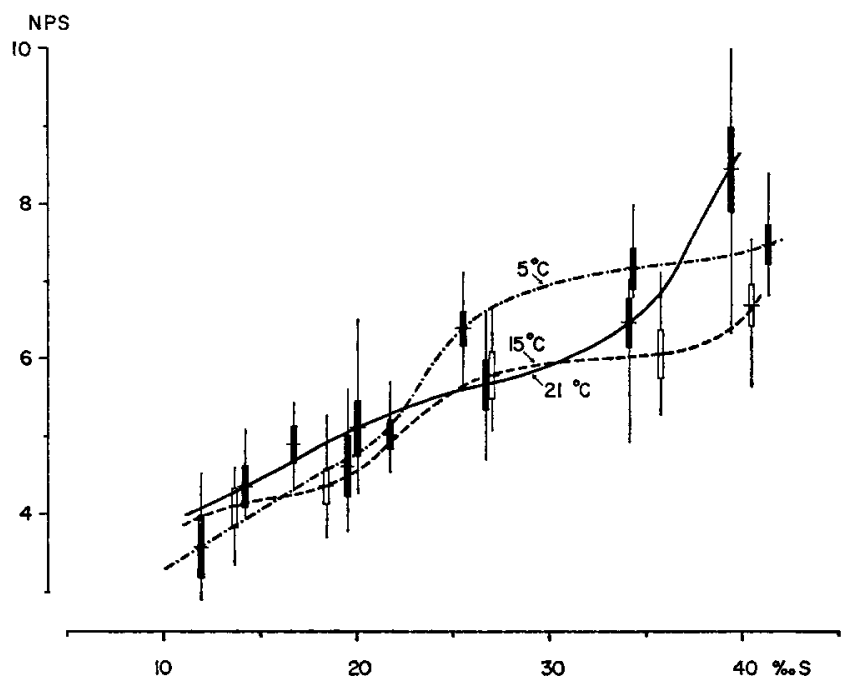

Fig.2. The concentration of ninhydrin-positive substance, NPs (expressed in $\mathrm{mg} \mathrm{N} / \mathrm{g}$ fresh weight) in muscle of $C$. crangon adapted to various salinities at $5^{\circ}, 15^{\circ}$ and $21^{\circ} \mathrm{C}$. The vertical and the short horizontal lines indicate, respectively, the range of values and the mean. The total height of each column represents one standard deviation; solid, open and shaded columns refer, respectively, to acclimation temperatures of $21^{\circ}, 15^{\circ}$ and $5^{\circ} \mathrm{C}$. At each salinity-temperature combination 7 to 10 determinations were made. The obliquely-shaded columns (at the 3 lower salinities) are from a second experimental series on a separate batch of shrimps which show the same essential features, but where only 4 determinations were carried out at each salinity.

For significance of temperature induced variation see Table I.

It will be evident (Fig. 2) that the relation between muscle NPS and salinity is not linear; all experiments indicated stronger NPs regulation in the "middle" range of salinities, in contrast to a more marked salinity dependency at the more extreme low and high salinities. In the regulation-range of salinities, the NPs concentration at $5^{\circ} \mathrm{C}$ is significantly higher than at the other acclimation temperatures studied. The influence of temperature is also complex; whereas the regulation range may be characterized by an inverse temperature correlation, the curves in Fig. 2 tend to cross-over at high and at low salinities, producing a direct correlation under these conditions. It may further be noted that combination of low temperature with low salinity, and particularly of high temperature with high salinity-i.e. conditions which have been shown unfavourable to survival of North- and Wadden 
Sea Crangon specimens (BRoEkema, 1941)-are correlated respectively with strong decrease and increase of cellular NPs. A duplicate of the entire experimental series confirmed the essential features here stipulated.
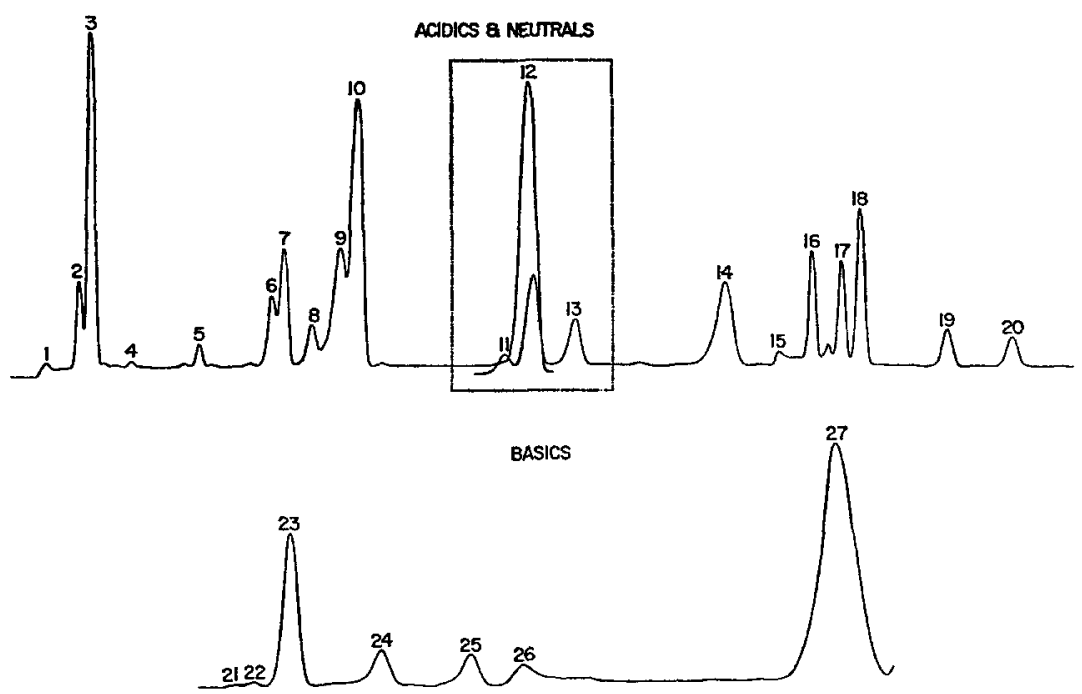

Fig.3. Elution patterns of ninhydrin-positive constituents of muscle extract of specimens of $C$. crangon, adapted to $31,2 \% \mathrm{~S}$ and $5^{\circ} \mathrm{C}$. The continuous line represents the $570 \mathrm{~nm}$ trace, the dotted line that at $440 \mathrm{~nm}$. The columns were loaded with $160 \mathrm{mg}$ freeze-dried material dissolved in $0.5 \mathrm{ml}$ buffer, the boxed section represents a seperate run in which this solution applied was diluted 21 times. The identification of the numbered peaks is as follows: 1 and 2 unidentified (phospho?) compounds; 3 , taurine ; 4, urea ; 5 , aspartic acid ; 6 threonine; 7 , serine; 8 , asparagine; 9 , glutamic acid; 10 , glutamine; 11 , proline; 12 , glycine; 13 , alanine; 14 , valine; 15 , buffer change; 16 , methionine; 17 , iso-leucine; 18 , leucine; 19 , tyrosine; 20 , phenylalanine; $21, \gamma$-amino butyric acid; 22 , ornithine; 23 , ammonia, 24 , lysine; 25 , histidine; 26 , buffer change; 27 , arginine.

\section{Free amino acids (FAA)}

An example of an elution pattern obtained in determining the concentrations of the individual free amino acids is shown (Fig. 3). The concentrations of some 20 amino acids and of taurine in muscles of shrimps adapted to 3 salinities at $5^{\circ} \mathrm{C}$ are given in Table II. The muscle concentrations per mg freeze-dried material is also expressed per unit fresh weight making use of the water content values (assuming that the freeze-dried and oven-dried material constitute the same fraction of fresh weight). It may be seen that the sum of the FAA illustrate the same salinity correlation as found for NPs, with concentra- 
TABLE II

The concentrations of amino acids and taurine (in $\mu$ mole) of muscle tissue of $C$. crangon adapted to three salinities.

\begin{tabular}{|c|c|c|c|c|c|c|}
\hline & \multicolumn{2}{|c|}{$17.1 \% \mathrm{~s}$} & \multicolumn{2}{|c|}{$31.2 \% \mathrm{~S}$} & \multicolumn{2}{|c|}{$40.8 \% S$} \\
\hline & $\begin{array}{c}\text { per } m g \\
\quad d r y \\
\text { weight }\end{array}$ & $\begin{array}{c}\text { per } g \\
\text { fresh } \\
\text { weight }\end{array}$ & $\begin{array}{c}\text { per } m g \\
\quad d r y \\
\text { weight }\end{array}$ & $\begin{array}{c}\text { per } g \\
\text { fresh } \\
\text { weight }\end{array}$ & $\begin{array}{c}\text { per mg } \\
\text { dry } \\
\text { weight }\end{array}$ & $\begin{array}{c}\text { per } g \\
\text { fresh } \\
\text { weight }\end{array}$ \\
\hline \multicolumn{7}{|l|}{$\begin{array}{l}\text { Acidic and neutral } \\
\text { amino acids }\end{array}$} \\
\hline aspartic acid & 0.0002 & 0.04 & 0.0010 & 0.23 & 0.0013 & 0.32 \\
\hline threonine & 0.0052 & 1.13 & 0.0039 & 0.91 & 0.0101 & 2.46 \\
\hline serine & 0.0076 & 1.66 & 0.0069 & 1.61 & 0.0082 & 2.00 \\
\hline asparagine & 0.0031 & 0.68 & 0.0028 & 0.65 & 0.0040 & 0.97 \\
\hline glutamine & 0.0360 & 7.85 & 0.0344 & 8.02 & 0.0370 & 9.01 \\
\hline glutamic acid & 0.0126 & 2.75 & 0.0151 & 3.52 & 0.0292 & 7.11 \\
\hline proline & 0.1942 & 42.33 & 0.1204 & 28.07 & 0.4199 & 102.24 \\
\hline glycine & 0.4902 & 106.84 & 1.0031 & 233.88 & 0.7749 & 188.68 \\
\hline alanine & 0.0982 & 21.40 & 0.0756 & 17.63 & 0.2745 & 66.84 \\
\hline valine & 0.0087 & 1.90 & 0.0097 & 2.26 & 0.0134 & 3.26 \\
\hline methionine & 0.0033 & 0.72 & 0.0052 & 1.21 & 0.0058 & 1.41 \\
\hline isoleucine & 0.0042 & 0.92 & 0.0049 & 1.14 & 0.0065 & 1.58 \\
\hline leucine & 0.0093 & 2.03 & 0.0091 & 2.12 & 0.0118 & 2.87 \\
\hline tyrosine & 0.0028 & 0.61 & 0.0025 & 0.58 & 0.0038 & 0.92 \\
\hline phenylalanine & 0.0020 & 0.44 & 0.0022 & 0.51 & 0.0022 & 0.54 \\
\hline subtotal & 0.8776 & 191.30 & 1.2968 & 302.34 & 1.6026 & 390.21 \\
\hline \multicolumn{7}{|l|}{ Basic amino acids } \\
\hline$\gamma$-am. butyric acid & trace & trace & trace & trace & trace & trace \\
\hline ornithine & 0.0003 & 0.07 & trace & trace & 0.0005 & 0.12 \\
\hline lysine & 0.0218 & 4.75 & 0.0041 & 0.96 & 0.0090 & 2.19 \\
\hline histidine & 0.0032 & 0.70 & 0.0041 & 0.96 & 0.0048 & 1.16 \\
\hline arginine & 0.0978 & 21.32 & 0.0833 & 19.42 & 0.0782 & 19.04 \\
\hline subtotal & 0.1231 & 26.84 & 0.0915 & 21.34 & 0.0925 & 22.51 \\
\hline Taurine & 0.0276 & 6.02 & 0.0421 & 9.82 & 0.0292 & 7.11 \\
\hline total & 1.0283 & 224.16 & 1.4304 & 333.50 & 1.7243 & 419.83 \\
\hline
\end{tabular}

tions of approximately $0.22,0.33$ and $0.42 \mathrm{mmole} / \mathrm{g}$ fresh weight, respectively at 17,31 and $41 \%$ S. It will also be evident that proline, glycine and alanine-and to a lesser extent arginine-are the predominating amino acids. In order to facilitate comparison, the concentrations per unit fresh weight of both total FAA and of NPS (the latter again being calculated by assuming the presence of a single ninhydrin positive N-atom per molecule NPS) are incorporated in histograms (Fig. 4). It is seen that the amino acids constitute some 67 to $79 \%$ of muscle ninhydrin-positivity. In view of the low ninhydrin colour yield 
of the imino acid proline, these values, however, only represent approximations. Presumably the difference between NPS and FAA may largely be accounted for by ammonia.

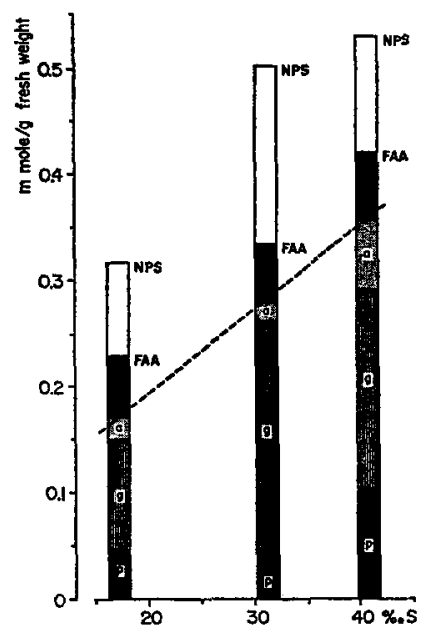

Fig.4. Histograms representing the concentrations (in mmole/g fresh weight) of proline (p), glycine (g), alanine (a), total free amino acid concentration (FAA) and of ninhydrin-positive substance (NPS) in muscle of $C$. crangon acclimated to salinities of $17.1 \% \mathrm{~S}, 31.2 \% \mathrm{~S}$ and $40.8 \% \mathrm{~S}$ at $5^{\circ} \mathrm{C}$.

It is now clear that amino acids by and large account for the salinity dependent variation in muscle NPs, and that the FAA variation is in itself a reflection of the combined concentrations of the main amino acids, proline, glycine and alanine. Although the individual concentrations of these three amino acids lack a linear correlation with environmental salinity, their total fractional contribution to FAA even increases with increasing salinity. An increase in salinity from 17 to $30 \% \mathrm{~S}$ is associated with a strong increase in glycine; at higher salinities proline and alanine seem to increase at the partial expense of glycine. Assuming that amino acids behave like ideal solutes, these amino acids alone may be calculated to account for freezing point depressions of $0.41,0.68$ and $0.88^{\circ} \mathrm{C}$ at the three acclimation salinities in question. The strong variation in concentration of these three non essential amino acids align with the view that they are regulated by reversible synthesis-degradation (GiLles \& SchoffENIELS, 1969).

Despite the marked salinity influence on cellular FaA, Fig. 4 suggests that the higher NPS value induced by low temperature $\left(5^{\circ} \mathrm{C}\right)$ in the regulation range results from an increase in non-amino-acid nitrogenous compounds. 
It should, however, be born in mind that all concentrations recorded per unit muscle weight are inclusive of those in extracellular fluid. In view of the low haemolymph NPS and FAA content (page 404) the extracellular contribution will, however, be small. For Homarus vulgaris, CAmIEN et al. (1951) in fact record that the extracellular fluid only contains some $15 \%$ of the haemolymph amino acid content. During homogenation the extracellular fluid will thus dilute the cellular concentrations. Preliminary experiments in our laboratory have, however, indicated a very small extracellular volume Crangon abdominal muscle, the inulin space being approximately $6.2 \%$-a result which seems in accordance with the solid nature of the muscle tissue. Assuming for lack of such data that in Crangon the extracellular NPs concentration equals that in the haemolymph, it follows that the recorded NPS values will represent some $94 \%$ of the real intracellular concentrations. Since the inulin space may become reduced with decreasing salinities -in the oyster Gryphaea it amounts to $9.6 \%$ in sea water, and $5.9 \%$ in $50 \%$ sea water (BRICTEUX-GRÉGOIRE et al., 1964) - the here recorded values may thus approximate the real intracellular values even more closely under these conditions. It may be noted here that for the lobster $\mathcal{N}$ ephrops norvegicus, and the cephalopod molluscs Sepia and Eledone, Robertson (1961; 1965) records inulin spaces of $12,8.5$ and $14.7 \%$, respectively.

\section{HAEMOLYMPH CONGENTRATIONS}

Ninhydrin-positive substance (NPS)

The concentration of NPS in haemolymph is very low, only about one per cent of that in muscle tissue, and subject to a strong individual variation which necessitated a large number of observations (Fig. 5).

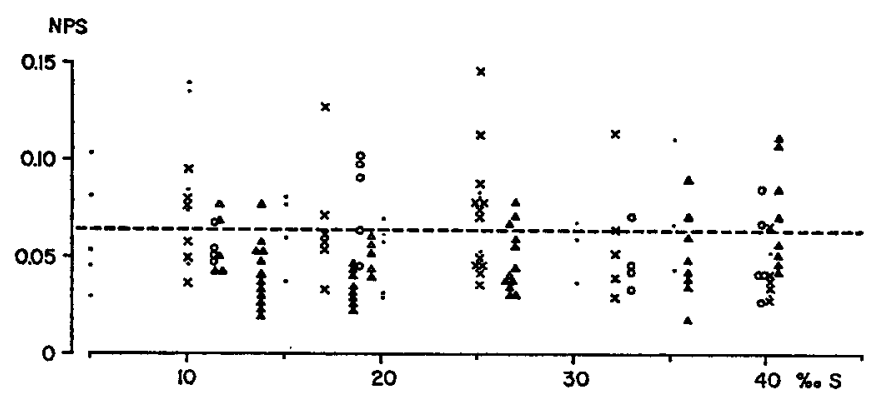

Fig.5. The concentration of NPs (in $\mathrm{mg} \mathrm{N} / \mathrm{ml}$ ) in haemolymph of C. crangon acclimated to various salinities at $15^{\circ} \mathrm{C}$. Each point represents an individual shrimp. Different symbols refer to observations from different experimental series. 
The relation between haemolymph NPS concentration in mg equivalents leucine- $\mathrm{N} / \mathrm{ml}$ haemolymph, and salinity in \%o $(S)$ may be characterized by the following calculated regressions:

$$
\begin{aligned}
& \text { at } 5^{\circ} \mathrm{C} \text {, NPs }=-0.01 S+0.0954(\mathcal{N}=112), \\
& \text { at } 15^{\circ} \mathrm{C} \text {, NPs }=-0.02 S+0.0645(\mathcal{N}=142), \\
& \text { at } 21^{\circ} \mathrm{C} \text {, NPS }=-0.06 S+0.0435(\mathcal{N}=65) .
\end{aligned}
$$

These data indicate that the haemolymph NPS is essentially independent of acclimation salinity and that the dissolved FAA and other NPS account for a freezing point depression of less than $0.01^{\circ} \mathrm{C}$ of the total haemolymph value. Despite this negligible contribution it is remarkable that the temperature effect resembles that of both haemolymph osmolarity and tissue NPS in the regulation range, in attaining distinctly higher values at $5^{\circ} \mathrm{C}$ than at $15^{\circ}$ and $21^{\circ} \mathrm{C}$.

\section{Free amino acids (FAA)}

Determinations of the concentrations of individual amino acids in the haemolymph of shrimps acclimated to 3 salinities at $15^{\circ} \mathrm{C}$ (Table III) are in accordance with the low NPs values recorded above. Parallel determinations carried out directly and after 6 months on subsamples, moreover show that deep-frozen storage $\left(\right.$ at $-18^{\circ} \mathrm{C}$ ) hardly influences the acidic and neutral amino acid concentrations, with the exception of tyrosine which disappears.

Seen in conjunction with the NPs data the fact that haemolymph FAA only seems subject to increase above $28 \% \mathrm{~S}$, suggests an increased participation of non-amino-acid nitrogen at lower salinities.

Comparison with muscle concentrations reveal interesting features. While glycine, proline and alanine again constitute the main amino acids in the haemolymph, their fractional contribution here is considerably lower ( 40 to $45 \%$ ) than in tissues ( 76 to $85 \%$ ). Whereas the amino acids which may be considered non-essential to crustaceans, aspartic and glutamic acids, serine, proline, glycine, alanine and tyrosine ( $c f$. ZANDEE, 1966: Astacus astacus) form 78 to $88 \%$ of muscle FAA, it only accounts for some 47 to $53 \%$ of that in haemolymph. This indicates relatively greater concentrations of the essential amino acids in the haemolymph, particularly of lysine which may form 8 to $10 \%$ of haemolymph FAA (Table III). It is particularly significant, however, that the non-essential proline conforms rather with the distribution of the essential amino acids in making an equal and even increased fractional contribution to haemolymph FAA (20 to $27 \%$ ) than to muscle tissue FAA (9 to $24 \%$ ). These observations are thus in complete accordance with results of Gilles \& Schoffeniels (1969) on isolated 
TABLE III

The concentrations of amino acids and taurine (in $\mu \mathrm{mole} / \mathrm{ml}$ ) in the haemolymph of $C$. crangon adapted to 3 salinities. Of the haemolymph from $14.5 \% \mathrm{~S}$ adapted shrimps a subsample was analysed directly; a second subsample and the samples from shrimps adapted to the other salinities were determined after 6 month's deepfrozen storage of the freeze-dried material; nd = not determined.

\begin{tabular}{|c|c|c|c|c|}
\hline & \multicolumn{2}{|c|}{$14.5 \% s$} & \multirow{2}{*}{$\frac{27.6 \%{ }_{00} S}{\text { Stored }}$} & \multirow{2}{*}{$\frac{36.6 \% \mathrm{~S}}{\text { Stored }}$} \\
\hline & $\begin{array}{l}\text { Directly } \\
\text { analysed }\end{array}$ & Stored & & \\
\hline \multicolumn{5}{|l|}{$\begin{array}{l}\text { Acidic and neutral } \\
\text { amino acids }\end{array}$} \\
\hline aspartic acid & 0.042 & 0.037 & 0.024 & 0.053 \\
\hline threonine & trace & 0.002 & trace & 0.009 \\
\hline serine & 0.122 & 0.109 & 0.108 & 0.556 \\
\hline asparagine-glutamine & 0.189 & 0.217 & 0.182 & 0.465 \\
\hline glutamine acid & 0.087 & 0.105 & 0.118 & 0.144 \\
\hline proline & 0.581 & 0.648 & 0.726 & 1.863 \\
\hline glycine & 0.249 & 0.244 & 0.252 & 0.208 \\
\hline alanine & 0.409 & 0.391 & 0.492 & 0.766 \\
\hline valine & 0.073 & 0.088 & 0.096 & 0.291 \\
\hline methionine & 0.011 & 0.020 & 0.019 & 0.060 \\
\hline isoleucine & 0.071 & 0.079 & 0.074 & 0.243 \\
\hline leucine & 0.098 & 0.111 & 0.105 & 0.366 \\
\hline tyrosine & 0.027 & - & - & 一 \\
\hline phenylalanine & 0.024 & 0.031 & 0.038 & 0.122 \\
\hline subtotal & 1.983 & 2.082 & 2.234 & 5.146 \\
\hline \multicolumn{5}{|l|}{ Basic amino acids } \\
\hline$\gamma$-amino butyric acid & nd & trace & trace & trace \\
\hline ornithine & nd & 0.013 & 0.006 & 0.012 \\
\hline lysine & nd & 0.338 & 0.265 & 0.626 \\
\hline histidine & nd & 0.027 & 0.045 & 0.101 \\
\hline arginine & nd & 0.216 & 0.182 & 0.385 \\
\hline subtotal & & 0.594 & 0.498 & 1.124 \\
\hline Taurine & 0.439 & 0.564 & 0.502 & 0.493 \\
\hline total & & 3.240 & 3.234 & 6.763 \\
\hline
\end{tabular}

surviving nerves of Eriocheir indicating that modification in the permeability in the cell membranes, and associated extrusion from cells, are implicated in the regulation of concentrations of essential amino acids and of proline in the cells.

The quantitative differences in amino acid composition of haemolymph and muscle simultaneously illustrate that the measured haemolymph concentrations do not merely represent leakage from the cells during collection of the haemolymph samples. 


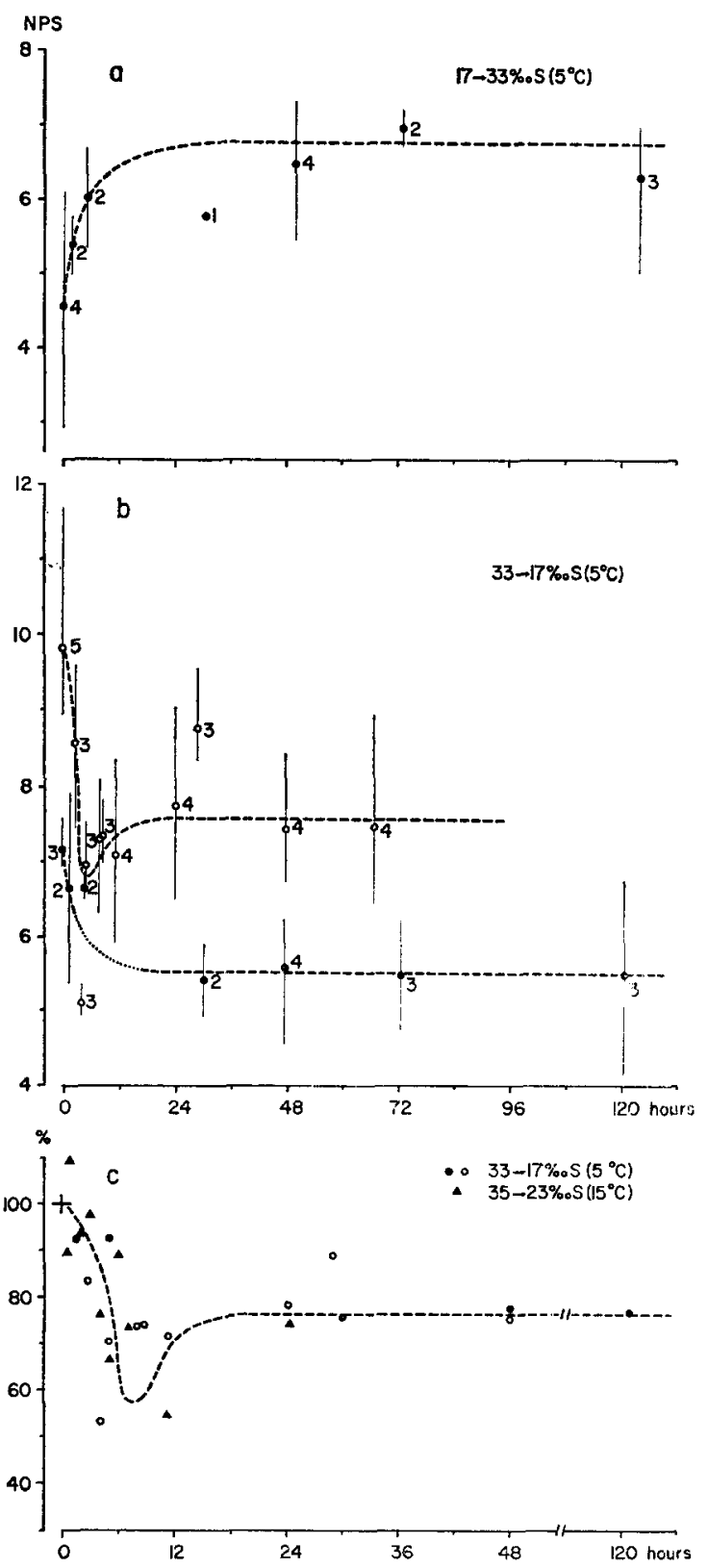




\section{ACGOMMODATION RATE}

The rate of adaptation of muscle and haemolymph concentrations to changes in environmental salinity was studied in order to evaluate its biological significance to the shrimps which in the Wadden Sea are regularly subjected to strong salinity variations (PostmA, 1954), and to gain further insight into the possible coupling of regulatory mechanisms in these two tissues. This was effected by adapting shrimps for at least 6 days in hypo- and hyperosmotic salinities ( 17 and $33 \%$ S). The media of the shrimps were then suddenly interchanged, and the subsequent time dependent variation in muscle and haemolymph NPS concentrations were measured.

\section{Muscle tissue}

As expected the muscle NPS content of shrimps adapted to $17 \% \mathrm{~S}$ is seen to increase strongly after sudden transfer to $33 \%$ S at $5^{\circ} \mathrm{C}$ (Fig. 6a). Despite the considerable variation, it is evident that the accommodation is rapid and that the "half-time" value is in the order of 3 hours. In the counter-transfer, from $33 \% \mathrm{~S}$ to $17 \% \mathrm{~S}$ the "half-time" value is similarly brief (Fig. 6b) but the adaptation shows further evidence for an "overshoot" effect ( $c f$. KINNE, 1964). It may be noted that corresponding under- and overshoots have been found in the amino acid levels in the fish Platypoecilus maculatus during acclimation to diluted sea water and the subsequent return to sea water (ANDERs et al., 1962). The adaptation rate at $15^{\circ} \mathrm{C}$ does not seem significantly higher than at $5^{\circ} \mathrm{C}$ (Fig. 6c) unlike the clear temperature influence on the corresponding accommodation rate of haemolymph osmolarity (WeBER \& SpaARgaren, 1970).

\section{Haemolymph}

Transfer of shrimps from hypo- to hyperosmotic salinity (17 to $33 \%$ S) seems associated with a slight and insignificant fall in haemolymph NPS (Fig. 7a). For the opposite transfer, from 33 to $17 \%$ S (Fig. $7 \mathrm{~b}$ ), the

Fig.6. Variation in muscle NPs (in $\mathrm{mg} \mathrm{N} / \mathrm{g}$ fresh weight) with time (in hours) following salinity transfer at $5^{\circ} \mathrm{C}$. The symbols and vertical lines represent respectively the means and the range of the values found; the figures indicate the number of determinations (each using a separate individual). a. Transfer from hypo- to hyperosmotic salinity (17 to $33 \% \mathrm{~S}$ ) at $5^{\circ} \mathrm{C}$. b. Transfer from hyper- to hypoosmotic salinity (33 to $17 \%$ S) at $5^{\circ}$ C. c. Variation in the mean NPS values after transfer from hyper- to hypoosmotic salinity as a percentage of the mean initial value. Open and closed circles represent values from $\mathrm{Fig} .2 \mathrm{~b}$; triangles show the corresponding variation following a transfer from 35 to $23 \% \mathrm{~S}$ at $15^{\circ} \mathrm{C}$, where each symbol represents a mean value of 3 determinations. 
large temporary increase in the haemolymph concentration suggests that during the decrease in muscle values some ninhydrin-positive material is extruded into the haemolymph. It may be noted, however, that the increase in mean haemolymph concentrations concurs with a large increase in individual variation, and the possibility of pathological phenomena as distinct from a true regulation should not be excluded. In this respect it may be noted that Broekema (1941) has indicated that low salinities are unfavourable for the survival of Crangon at low temperatures and RoBerTson (1961) notes increasing equalization of muscle and plasma concentrations after death in Nephrops norvegicus. On the other hand it appears that the increases persist for 3 to 5 days at most.

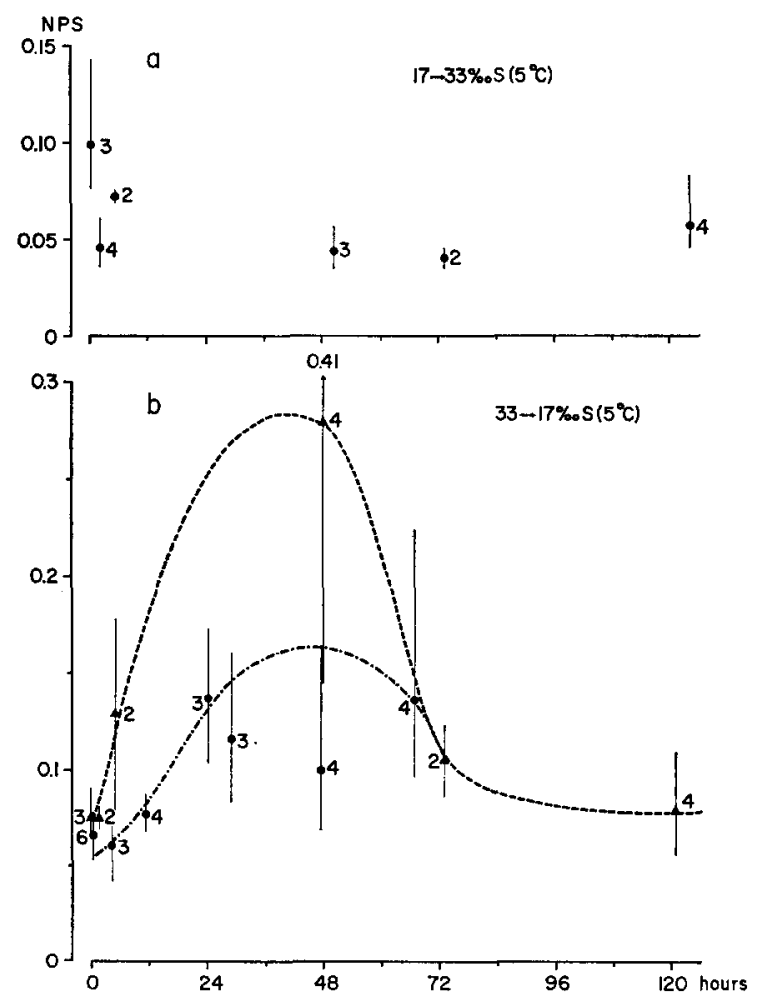

Fig.7. Variation in haemolymph NPS (in $\mathrm{mg} \mathrm{N} / \mathrm{ml}$ ) with time (in hours) following transfer (a) from hyper- to hypoosmotic salinity and (b) from hypo- to hyperosmotic salinity at $5^{\circ} \mathrm{C}$. 
IV. GENERAL DISCUSSION

The present data of NPS and FAA concentrations in muscle tissue of C. crangon illustrate clearly that mainly the cellular amino acids are involved in the adjustment of cellular osmotic pressures to those in the haemolymph following an alteration in external salinity. In view of the euryhaline conditions to which Crangon is regularly subjected-by virtue of the salinity variations in the Wadden Sea and of its seasonal migration-the ambient salinities will regularly fall outside the relatively narrow range in which the haemolymph osmotic concentrations are strongly regulated (Weber \& SpaARgaren, 1970). Since this regulation of haemolymph concentrations relieves the isosmotic intracellular regulation of part of its duty, the latter will become of increasing importance under these conditions. The rapid responses of the intracellular non-protein NPS to altered salinity here demonstrated (at least as rapid as the corresponding accommodation rate of haemolymph $\Delta$-values) would thus seem important in preventing excessive alteration in tissue water and consequent cell volume-changes.

The Crangon data, extending in contrast to previous studies over a wide range of temperature and salinity conditions, most clearly demonstrate the sensitivity of intracellular amino acids in their role of balancing haemolymph osmolarities. Accordingly, the previouslyrecorded pattern of haemolymph $\Delta$-variation under comparable experimental conditions (Weber \& SpaArgaren, 1970) is now seen reflected in a strictly analogous pattern of muscle NPS regulation. Corresponding features include strong regulation of both at "middle" salinities, where the temperature effect is inverse, and strong conformity at high and at low salinities-particularly when the temperature-salinity combination is unfavourable to survival (page 399)where the temperature effect tends to become direct. Comparison with the pattern of haemolymph osmotic regulation, however, reveals that the muscle NPs regulation pattern is shifted to higher salinities. This is indicative of a slight increase in cellular electrolyte concentrations at higher salinities, as has in fact been evidenced from conductivity measurements of whole animal homogenates (SPAARGAREN, 1971: Figs $21 \mathrm{a}$ and $\mathrm{b}$ ). In view of the interpopulation plasticity of the haemolymph regulation pattern in Crangon (WEBER \& SPAARgaren, 1970), inherent variation in the experimental material as causal factor can not be excluded, however.

The quantitative correspondence of salinity-dependent variation in tissue NPS and in haemolymph osmolarity, is in accordance with the concept that the tissue nitrogenous component enables the maintenance of the intracellular electrolyte concentrations within limits compatible for an efficient functioning of metabolic processes. The 
extensive literature on the marked effects of total ionic strengths and of several individual ions on the activity of enzymes and on conformational effects of other essential proteins amply substantiate this view.

The temperature effect may be compared with data available from literature. For muscle of Eriocheir sinensis adapted to fresh water at temperatures of respectively 1 to $3^{\circ} \mathrm{C}$ and 10 to $11^{\circ} \mathrm{C}$, Duchâteau $\&$ FLORKIN (1955) find that although the concentrations of glycine-and after long acclimation also those of alanine and arginine-correlate inversely with temperature; the total FAA is higher at the higher acclimation temperature particularly as a result of a marked increase in proline. This direct temperature interaction in fresh water aligns with that indicated for $C$. crangon at low salinities. Again, it may be noted that similar to Crangon muscle tissue at about $25 \% \mathrm{~S}$, the muscle of the bivalve Mya arenaria shows an inverse temperature effect, containing at $25^{\circ} \mathrm{C}$ only $88 \%$ of the FAA of $8^{\circ} \mathrm{C}$-adapted animals (Du PAUl \& WebB, 1970). For the crab Paratelphusa sp. living in fresh water the haemolymph amino acid content shows an inverse temperature effect at $26^{\circ} \mathrm{C}$ and $33^{\circ} \mathrm{C}$, while the reverse holds for the haemolymph concentrations in the fresh water mussel Lamellidens marginalis (Pampapathi-Rao \& Ramaghandra, 1961). It is clear that much comparative research of the temperature influence on the FAA in tissues of marine invertebrates is needed before a general interpretation of the possible osmoregulatory significance can be extracted. The fact that both the nature and the magnitude of the temperature effect in Crangon depends on the prevailing salinity, illustrates its complexity.

Although the total FAA concentration in muscle shows positive salinity correlation, a disproportionate salinity variation of the individual amino acids has been noted. Similar findings are reported by LyNCH \& WoOD (1966) for the adductor muscle of the oyster Crassostrea virginica taken from different salinities. Although here alanine is the main amino acid at low salinities its fractional contribution decreases at higher salinities due to the increased participation of taurine and to a lesser extent of glycine and proline. These results favour the idea that marine invertebrates possess a mechanism which regulates both the quantity and the quality of the osmotically-significant tissue amino acids. It is further significant to note that the osmotic adjustment of Crangon tissue cells is mainly affected by variation in 3 non-essential amino acids (Fig. 4) and that for Mytilus edulis LANGE (1963) considers that as an osmotic effector taurine, being abundant, salinity-sensitive, and an excretory product, presumably exerts a sparing effect on other amino acids that may be more essential to cellular metabolism.

The low concentrations of FAA and taurine in the haemolymph 
(about $3.2 \mathrm{mmole} / \mathrm{l}$ at approximately $15 \%$ and $28 \% \mathrm{~S}$ and $6.8 \mathrm{mmole} / 1$ at $37 \% \mathrm{~S}$ ) are in accordance with those recorded for crustacean haemolymph (generally below 6 mmole/l) ( $c f$. CAMIEN et al., 1951; VincentMarique \& Gilles, 1970). These Crangon values may be calculated to account for a $\Delta$-value of less than $0.01^{\circ} \mathrm{C}$ while some $0.2^{\circ} \mathrm{C}$ seems attributable to organic constituents in the haemolymph (SPAARGAREN, 1971). Although the haemolymph amino acid concentrations amount to only some one percent that in whole muscle tissue the mutual differences are quantitative rather than qualitative.

It is interesting to consider the measured muscle and haemolymph concentrations and their variation after salinity change in terms of proposed theories on the mechanism of amino acid regulation. While the adaptation to increased salinities produces an expected logarithmic increase in muscle NPS and no significant change in haemolymph NPS, acclimation to lower salinities seems complex (Fig. 6b and c) and indicates that some tissue NPS is extruded into the haemolymph where it produces amino acidemiae during at least 3 days. These data correlate well with the rapid increases in haemolymph non-electrolyte in the mediterranean prawns Palaemon serratus and Lysmata seticaudata following their sudden transfer to low salinities, as shown by SpaARGAREN (1972) on the basis of discrepancies between osmotic and conductivity measurements. Similar evidence for a transfer from the cells to the haemolymph is provided by the 6 -fold increase in the proline concentration of haemolymph of Eriocheir 4 days after transference from sea water to fresh water (Vincent-Marique \& Gilles, 1970a, $1970 \mathrm{~b})$, and the observation that this amino acid unlike the other nonessential ones, is regulated in part by changes in cell membrane permeability (Gilles \& Schoffeniels, 1969). In this respect it is significant that in Crangon proline and the essential amino acids make a greater fractional contribution to the amino acid pool of the haemolymph than to that of muscle tissue (see page 404).

Interesting comparative information is provided by observations on isolated muscle fibres from the crab Callinectes sapidus (LANG \& GAINER, 1969) where transfer to hypo-osmotic saline is accompanied by a rapid volume readjustment response, indicative of an efficient isosmotic intracellular regulation. In response to hyperosmotic conditions (comparable to the $17 \%$ to $33 \% \mathrm{~S}$ transfer in this study) however, only the expected decrease in fibre volume is seen, without the secondary tendency to revert to original dimensions, even after a 4-hour period. Vincent-MaRiQue \& Gilles (1969) interpret these results as evidencing a rapid mechanism of volume regulation during adaptation to hypo-osmotic media and a slower one in the case of hyper-osmotic stress. Related to the here indicated exchange of osmotic material 
with haemolymph, it may be pointed out that LANG \& GAINER's hyperosmotic experiment does not represent true in vivo conditions in view of the absence of haemolymph which in life may serve as link with pools of amino acids and their precursors in other tissues. The present data moreover show that adaptation of Crangon tissue to both hyper- and hypoosmotic salinities proceed at a rapid rate, despite the additional mediation in living animals of the anisosmotic extracellular regulation.

The use of cellular amino acids in osmotic adjustment of the cells implies that the degradation of amino acids is associated with a net reduction in osmotic activity of the products. This suggests that the solute regulation may consist for a large part of storage of solutes in an osmotically-inactive form. SHAW (1958) found Carcinus muscle fibres to be 7 to $8 \%$ hyper-osmotic to haemolymph and attributes this result to in vitro breakdown of arginine phosphate and ATP. For Crangon a comparison of the freezing point depressions of whole animal homogenates with those of the haemolymph (SPAargaren, 1971), shows that while the total body fluid-and thus probably the intracellular fluid-is isosmotic with haemolymph, homogenation seems to immobilize an osmotic reserve equivalent to $86 \mu$ mole $\mathrm{NaCl} / \mathrm{g}$. The fact that ground mammalian muscles evidence a similar rapid decrease in freezing point, indicate that this is a general phenomenon which may have become profitably exploited in the osmotic adaptation of marine invertebrates (see also SHAw, 1958). It is possible that the gel physicochemical nature of the cell interior-a condition to which the nitrogenous compounds themselves contribute, and which seems operative in reducing the activity of water (FLoRkin \& Schoffeniels, 1969)-is similarly involved in the regulation of osmotic activities of organic solutes.

\section{SUMMARY}

Measurements of the concentrations of ninhydrin positive substance (NPS) and of the individual free amino acids in muscle and haemolymph of Crangon crangon, adapted to various salinities at different temperatures, are recorded, and their significance as osmotic effectors is evaluated.

The pattern of NPS regulation in muscle under various environmental conditions being strictly analogous with that of the haemolymph osmotic regulation, illustrates its importance to the osmotic adjustment of the cells in response to changes in environmental conditions. The salinity-induced variation in NPS in turn reflects the total concentrations of the 3 most abundant amino acids: glycine, proline and alanine.

Parallel measurements of muscle and haemolymph NPs during the course of adaptation to hyper- and hypo-osmotic salinities evidence an 
ecologically-significant rapid response of the isosmotic intracellular regulation, and indicate an exchange of nitrogenous material across the cell membranes.

The results are discussed comparatively and with regard to the theories on the regulation of the nitrogenous contents and osmotic concentrations in the cells.

\section{REFERENCES}

Anders, F. Vester, K. Klinke \& H. Schumacher, 1961. Genetische und biochemische Untersuchungen über die Bedeutung der freien Aminosäuren für die Tumorgenese bei Art- bzw. Gattungsbastarden lebendgebärender Zahnkarpfen (Poeciliidae).-Biol. Zbl. 81 : 45-65.

Broekema, M. M. M., 1941. Seasonal movements and the osmotic behaviour of the shrimp Crangon crangon L.-Archs néerl. Zool. 6: 1-100.

Bricteux-Grégorre, S., G. Dughâteau-Bosson, G. Jeuniaux \& M. Florkin, 1964. Constituants osmotiquement actifs des muscles adducteurs de Gryphaea ungulata adaptée à l'eau de mer ou à l'eau saumâtre.-Archs int. Physiol. Biochim. 72: 835-842.

Camien, M. N., H. Sarlet, G. Duchâteau \& M. Florkin, 1951. Non-protein amino acids in muscle and blood of marine and fresh water Crustacea.-J. biol. Chem. 193: 881-885.

Chaplin, A. E., A. K. Huggins \& K. A. Munday, 1965. Ionic effects on glutamate dehydrogenase activity from beef liver, lobster muscle and crab muscle.Comp. Biochem. Physiol. 16: 49-62.

Clotten, R. \& A. Clotten, 1962. Hochspannungs Elektroforese. Georg Thieme, Stutgart: 73-113.

Cowey, C. B., 1961. The non-protein nitrogenous constituents of the tissues of the freshwater crayfish Astacus pallipes Lereboullet.-Comp. Biochem. Physiol. 2: $173-180$.

Drach, P., 1944. Étude préliminaire sur le cycle d'intermue et son conditionnement hormonal chez Leander serratus (Pennant).-Bull. biol. Fr. Belg. 78: 40-61.

Duchâteau, G. \& M. Florkin, 1955. Influence de la température sur l'état stationnaire du pool des acides aminés non protéiques des muscles d'Eriocheir sinensis Milne Edwards.-Archs int. Physiol. Biochim.-63: 213-221.

Duchâteau, G., M. Florkin \& C. Jeuniaux, 1959. Composante amino-acide des muscles de Carcinus maenas L. lors du passage de l'eau de mer à l'eau saumâtre et au cours de la mue.-Archs int. Physiol. Biochim. 67: 489-500.

Du PAUL, W. D. \& K. L. WEBB, 1970. The effect of temperature on salinity induced changes in the free amino acid pool of Mya arenaria.-Comp. Biochem. Physiol. 32: 785-801.

Emerson, D. N., 1966. Total free amino acid nitrogen in eleven species of snails: a consideration of some variable factors.-Proc. S. Dak. Acad. Sci. 45: 196-201.

Florkin, M., G. Dûchateau-Bosson, C. Jeuniaux \& E. Schoffeniels, 1964. Sur le méchanisme de la régulation de la concentration intracellulaire en acides aminés libres, chez Eriocheir sinensis, au cours de l'adaptation osmotique.Archs int. Physiol. Biochim. 72: 892-905.

Florkin, M. \& E. Schoffeniels, 1965. Euryhalinity and the concept of physiological radiation. In: K. A. MundAy, Studies in comparative biochemistry 23: $6-40$.

—, 1969. Molecular approaches to ecology. Academic Press, New York: 1-203. 
FLÜGEL, H., 1963. Electrolytregulation und Temperatur bei Crangon crangon L. und Carcinus maenas.--Kieler Meeresforsch. 19: 189-195.

FreDERICQ, L., 1901. Sur la concentration moleculaire du sang et des tissus chez les animaux aquatiques.-Bull. Classe Sciences 1 : $428-454$.

Fyнn, H. J., 1966. Function of the isosmotic intracellular regulation during moult in the shrimp Crangon vulgaris. Proc XII Scand. Congr. Physiol., Turku 1966.Acta physiol. scand. 68 (suppl. 277): 56.

Gilles, R., 1967. Aspects biochimiques de l'euryhalinité chez les crustacés.-Annls Soc. r. zool. Belg. 97: 31-34.

Gilles, R. \& E. Schoffeniels, 1969. Isosmotic regulation in isolated surviving nerves of Eriocheir sinensis Milne Edwards.-Comp. Biochem. Physiol. 31: 927-939.

HARRIs, R. R., 1969. Free amino acid and haemolymph concentration changes in Sphaeroma rugicauda (Isopoda) during adaptation to a dilute salinity.- J. exp. Biol. 50: 319-326.

Kaneshiro, E. S., G. G. Holz \& P. B. Dunham, 1969. Osmoregulation in a marine ciliate, Miamensis avidus. II. Regulation of intracellular free amino acids.-Biol. Bull., Woods Hole 137: 161-169.

KrnNe, O., 1964. Non-genetic adaptation to temperature and salinity.-Helgoländer wiss. Meeresunters. 9: 433-458.

LANG, M. A. \& H. Gainer, 1969. Volume control by muscle fibres of the blue crab. Volume readjustment in hypotonic salines.--J. gen. Physiol. 53: 323-341.

LANGe, R., 1963. The osmotic function of amino acids and taurine in the mussel, Mytilus edulis.-Comp. Biochem. Physiol. 10: 173-179.

-, 1970 . Isosmotic intracellular regulation and euryhalinity in marine bivalves.-J. exp. mar. Biol. Ecol. 5: 170-179.

LyNGH, M. P. \& L. Wood, 1966. Effects of environmental salinity on free amino acids of Crassostrea virginica Gmelin.-Comp. Biochem. Physiol. 19: 783-790.

Moore, S. \& W. H. Stein, 1948. Photometric ninhydrin method for use in the chromatography of amino acids.-J. biol. Chem. 176: 367-387.

Needham, A. E., 1957. Factors affecting nitrogen excretion in Carcinides maenas.-Physiologia comp. Oecol. 4: 209-239.

Pampapathi-Rao, K. \& R. Ramachandra, 1961. Effect of acclimation to high temperature on blood chloride, free amino acids and osmotic pressure in the freshwater field crab Paratelphusa sp. and the freshwater mussel Lamellidens marginales.-J. exp. Biol. 38: 29-34.

Pasantes, H., R. Tapia, B. Otega \& G. Massieu, 1965. Free amino acids and activity of some pyridoxal phosphate-dependent enzymes in the nervous system of three arthropod species.-Comp. Biochem. Physiol. 16: 523-529.

Postma, H., 1954. Hydrography of the Dutch Wadden Sea.-Archs néerl. Zool. 10: 405-511.

Prosser, G. L., 1965. Water: osmotic balance. In: C. L. Prosser \& F. A. Brown. Comparative animal physiology. Saunders, Philadelphia (2nd ed.): 6-56.

Robertson, J. D., 1961. Studies on the chemical composition of muscle tissue. II. The abdominal flexor muscles of the lobster Nephrops norvegicus (L.).-J. exp. Biol. 38: 707-728

- 1965 . Studies on the chemical composition of muscle tissue. III. The mantle muscle of cephalopod molluscs.-J. exp. Biol. 42: 153-175.

Schoffeniels, E., 1960. Origine des acides aminés intervenant dans la régulation de la pression osmotique intracellulaire de Eriocheir sinensis Milne Edw.-Archs int. Physiol. Biochim. 68: 696-698.

_ 1965 . L-glutamic acid dehydrogenase activity in the gills of Palinurus vulgaris 
Latr.-Archs int. Physiol. Biochim. 73: 73-80.

1968. The control of intracellular hydrogen transport by inorganic ions.Archs int. Physiol. Biochim. 76: 319-343.

SHAw, J., 1958. Osmoregulation in the muscle fibres of Carcinus maenas.-J. exp. Biol. 35: 920-929.

Simpson, J. W., K. Allen \& J. Awapara, 1959. Free amino acids in some aquatic invertebrates.-Biol. Bull., Woods Hole 117: 371-381.

SpaArgaren, D. H., 1971. Aspects of the osmotic regulation in the shrimps Crangon crangon and Crangon allmanni.-Neth. J. Sea Res. 5 (3): 275-333.

- 1972 . Osmoregulation in the prawns Palaemon serratus and Lysmata seticaudata from the Bay of Naples. - Neth. J. Sea Res. 5 (4): 416-436.

Spackman, D. H., W. H. Stein \& S. Moore, 1958. Automatic recording apparatus for use in the chromatography of amino acids.-Analyt. Chem. 30: 1190-1206.

VERWEY, J., 1957. A plea for the study of temperature influence on osmotic regulation.-Annls Biol. 33: 129-149.

Vincent-Marigue, C. \& R. Gilles, 1970a. Modification of the amino acid pool in blood and muscle of Eriocheir sinensis during osmotic stress.-Comp. Biochem. Physiol. 35: 479-485.

- $1970 \mathrm{~b}$. Changes in the amino acid concentration in blood and muscle of Eriocheir sinensis during hypoosmotic stress.-Life Sci. 9 (1): 509-512.

Weber, R. E. \& D. H. SPAARGAREN, 1970. On the influence of temperature on the osmoregulation of Crangon crangon and its significance under estuarine conditions. -Neth. J. Sea Res. 5: 108-120.

ZandeE, D. I., 1966. Metabolism in the crayfish Astacus astacus (L.). I. Biosynthesis of amino acids.-Archs int. Physiol. Biochim. 74: 35-44. 